\title{
Inner-City Neighbourhood Changes Predicted from House Prices in Windsor, Ontario, since the Early- or Mid-1980s
}

\author{
Alan G. Phipps \\ Department of Sociology, Anthropology and Criminology, University of Windsor, Windsor, Canada \\ Email:phipps@uwindsor.ca
}

How to cite this paper: Phipps, A.G. (2020) Inner-City Neighbourhood Changes Predicted from House Prices in Windsor, Ontario, since the Early- or Mid-1980s. Journal of Building Construction and Planning Research, 8, 138-160.

https://doi.org/10.4236/jbcpr.2020.82009

Received: May 6, 2020

Accepted: June 26, 2020

Published: June 29, 2020

Copyright $\odot 2020$ by author(s) and Scientific Research Publishing Inc. This work is licensed under the Creative Commons Attribution International License (CC BY 4.0).

http://creativecommons.org/licenses/by/4.0/

\begin{abstract}
Changes in prices of homes are hypothesized as correlated with the times of their sale and resale and the attributes of their dwelling unit and neighbourhood and those of neighbouring homes. They may also be correlated with the occurrences of events inside the neighbourhoods caused by the activities of individuals and organizations outside the neighbourhoods, such as whether the local economy is in a recession or has a high unemployment rate. Calibrated hybrid housing price models predict precipitous decreases in house prices of approximately 2900 sold and resold homes in two inner-city neighbourhoods in Windsor, Ontario, during those events since 1981 or 1986. Overall modest predicted percentage increases in houses' prices during more than 30 years therefore subsumed periods of inner-city neighbourhood deterioration in dispersed locations of unimproved and disimproved homes. Compensatory predictions however are of increasing prices for minorities of homes with improvements to several attributes of the dwelling unit and neighbourhood.
\end{abstract}

\section{Keywords}

Neighbourhood Change, House Price, Local Event, Hybrid Housing Price Model, Inner-City Neighbourhood

\section{Introduction}

Inmoving and outmoving residents as opposed to stayers are sources of most social, economic and environmental changes in a neighbourhood (e.g. [1] [2] [3] [4]). Movers however may sooner or later move again from their current locations, and so explanation of neighbourhood changes during a long study period 
may be complicated by participation of different (un-)observed individuals in those changes [5] [6]. In comparison, conventional houses remain in the same location long after residents have come and gone. Changes in the same homes' prices and their attributes of the dwelling unit and neighbourhood will thus be immobile indicators of the changes in a neighbourhood [7] [8]. This is because a home's sale price, or change in it, is generally hypothesized as a function of attributes of its dwelling unit, neighbourhood and location, and the changes in them; and its time of sale and time of resale if any; as well as the prices and attributes of neighbouring sold homes during the previous few months [9] [10] [11] [12].

In particular, homes' prices and attributes may get better or worse during occurrences of "local events" that are attributable to individuals' and organizations' activities inside or outside a neighbourhood. Impactful events originating outside a neighbourhood include declining employment or housing affordability, and a recessionary state of the economy or not; and those inside a neighbourhood include constructed or planned land use changes [13] [14]. Such events are therefore hypothesized in this study as producing fluctuations in prices of homes through time after controlling for the homes' attributes of the dwelling unit and neighbourhood [15] [16]. Quigley's [17] hybrid housing price model is calibrated for testing this hypothesis about changes in homes' prices in two inner-city neighbourhoods; and so this refines tests with single sales hedonic housing price models or repeat sales models in other studies (e.g. [18]-[23]). The tested data are the prices and the attributes of the dwelling unit and neighbourhood of all approximately 2900 sold homes in two inner-city neighbourhoods in Windsor, Ontario, since 1981 or 1986 depending on when data collection began.

This study therefore not only interprets neighbourhood changes in two inner-city neighbourhoods during long study periods in terms of changes in sold homes' prices and their attributes of the dwelling unit and neighbourhood. It also correlates predicted neighbourhood changes in houses' prices with occurrences of local events, hypothesized in the next section as caused by people's activities inside and outside those neighbourhoods. More precise predictions of changes in prices by a hybrid price model will be advantageous for diagnosing neighbourhood change, as this model is a statistical synthesis of both a single sales hedonic price model and a repeat sales model. In the end, hybrid models empirically predict very modest increases in house prices unless these prices are augmented by changes in sold homes' attributes of the dwelling unit and neighbourhood. These findings have methodological and practical implications for conclusions about changes in two inner-city neighbourhoods during the past more than 30 years.

\section{Local Events as Reasons for Changes in House Prices}

Four types of potentially-impactful events for a neighbourhood may be analogous to those hypothesized by Carson and Dastrup [16] as causing changes in 
the attributes of homes and their prices from one city to another. Hence for an $i^{\text {th }}$ home in an $n^{\text {th }}$ neighbourhood with a predicted change in price $\widehat{\Delta p}_{i}^{t}$ at time $t$.

$$
\widehat{\Delta p}_{i}^{t}=\mathcal{F}\left(B E_{n}^{t}, E C_{n}^{t}, H C_{n}^{t}, H P_{n}^{t}\right)
$$

where the first variable in Equation (1), $B E_{n}^{t}$, is the surrounding built environment if it has major new buildings and facilities or planned ones inside a neighbourhood that are capitalized in prices of nearby homes-or if outside of it, there are permits for new homes or completions of them in suburbs that siphon off demand for used houses, and decrease their prices [24] [25] [26]. For example, another study [27] speculates that house prices in two study neighbourhoods may have been stabilized by community planners' residential rehabilitation assistance programs in the early-1980s [28], and community improvement plans during the mid-2000s [29] [30]. Another speculation is the possibly benign effect on house prices of the opening of the so-called temporary casino in 1994 on the border of one neighbourhood, and its closure and replacement with the permanent casino in 1998 on the border of the other neighbourhood (Figure 1) [31]. Operationally, the casinos and the residential rehabilitation assistance programs are coded 1 for their operating years and zero otherwise, especially because the permanent casino has reportedly continuing land use impacts [32].

In comparison, the community improvement plans and four additional major construction or demolition projects near to or in the study neighbourhoods may have created beneficial (in-)accessibilities for a few years for some residents who work in them, play on them, or no longer see them; and so they are coded 1 for their first five years of (in-)existence and zero otherwise. Three constructions are a sculpture park along the Detroit riverbank in 1999 (Figure 2), a downtown corporate headquarters in 2002 (Figure 3), and a suburban sports arena in 2008

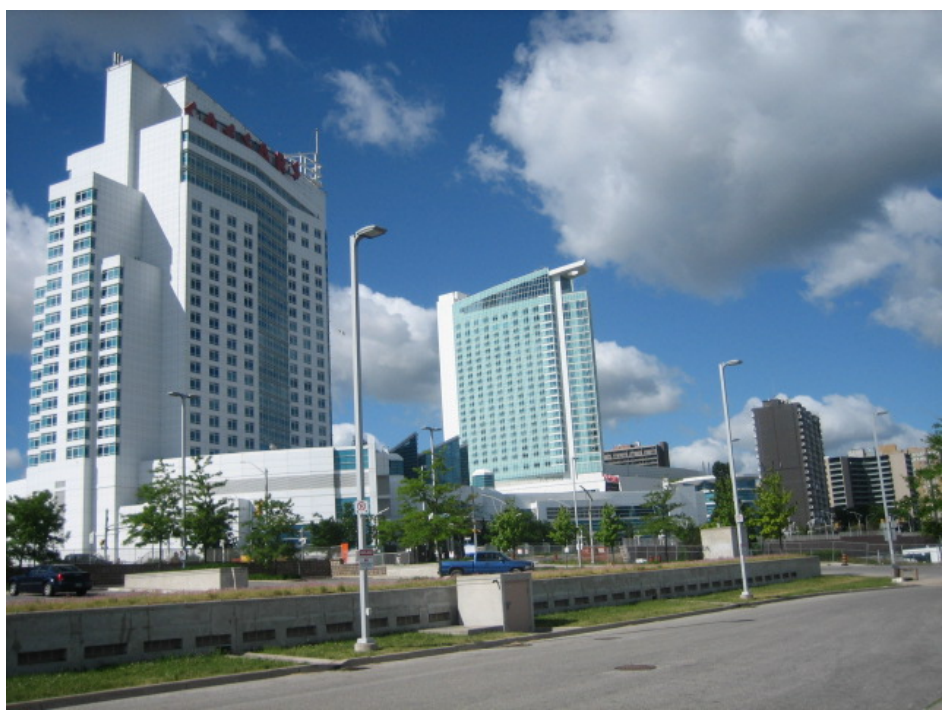

Source: Author.

Figure 1. Casino in downtown Windsor. 


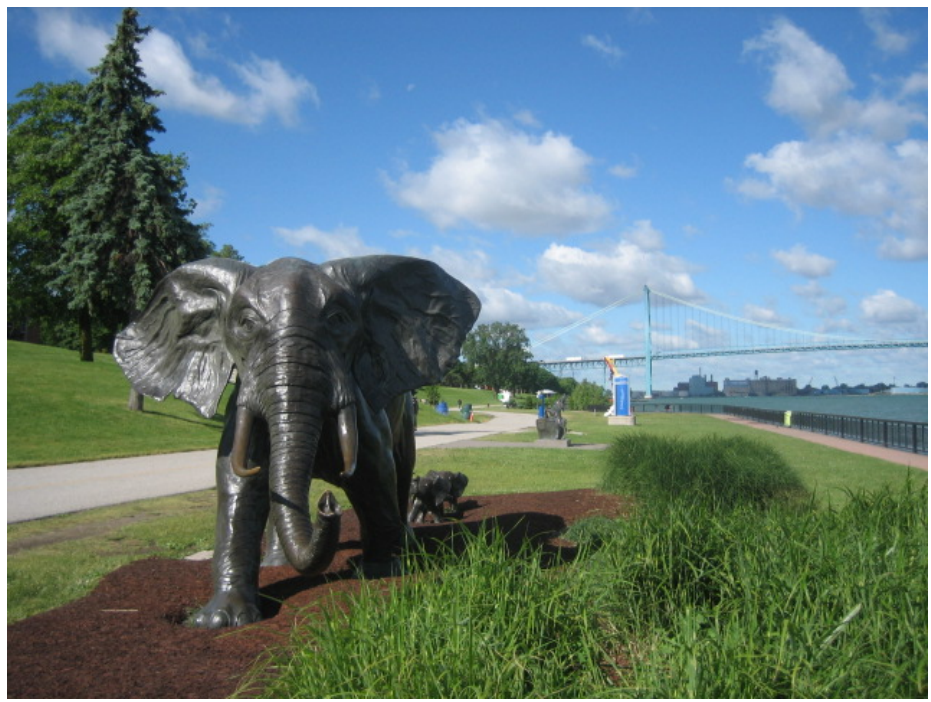

Source: Author.

Figure 2. Sculpture park along Detroit riverbank in Windsor.

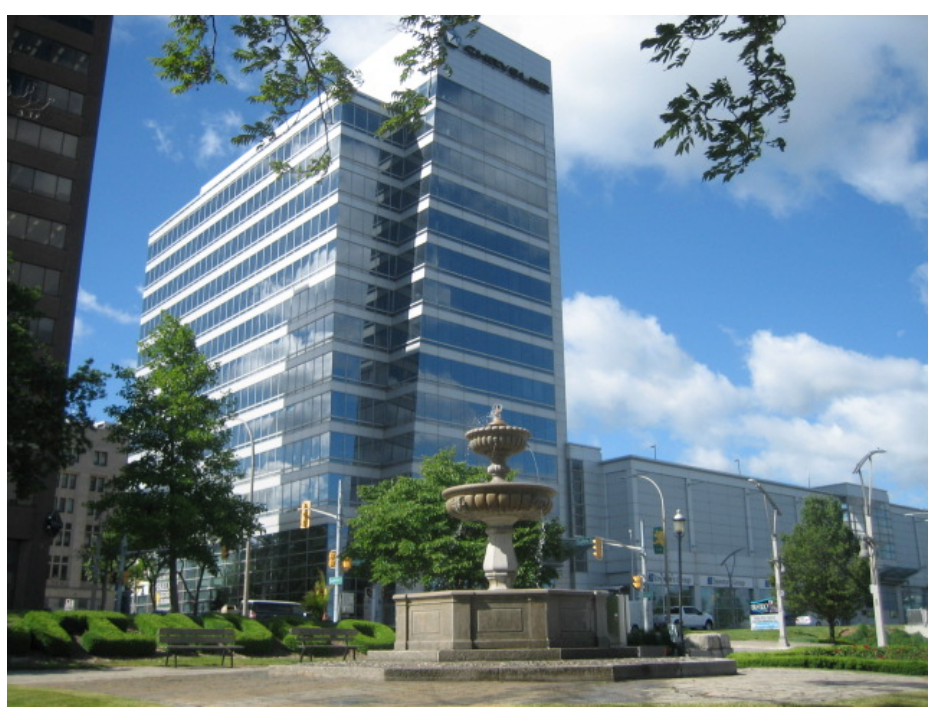

Source: Author.

Figure 3. Corporate headquarters in downtown Windsor.

instead of a retrofit in one study neighbourhood (Figure 4); and a fourth demolition in 2013 of a hospital closed in 2004 in the other study neighbourhood (Figure 5) [33] [34] [35]. Last, the study neighbourhoods contain few new single-detached and duplex houses, and so metropolitan Windsor's new residential building permits will be for properties located in far away suburbs. Operationally, monthly numbers of building permits aggregated to calendar years are prorated by metropolitan Windsor's corresponding annual estimated total population; and then lagged by one year as if used homes' prices react to a previous year's new construction [36] [37] [38]

The second variable in Equation (1), $E C_{n}^{t}$, is the state of the city-wide economy represented by the unemployment rate and presence or absence of an economic 


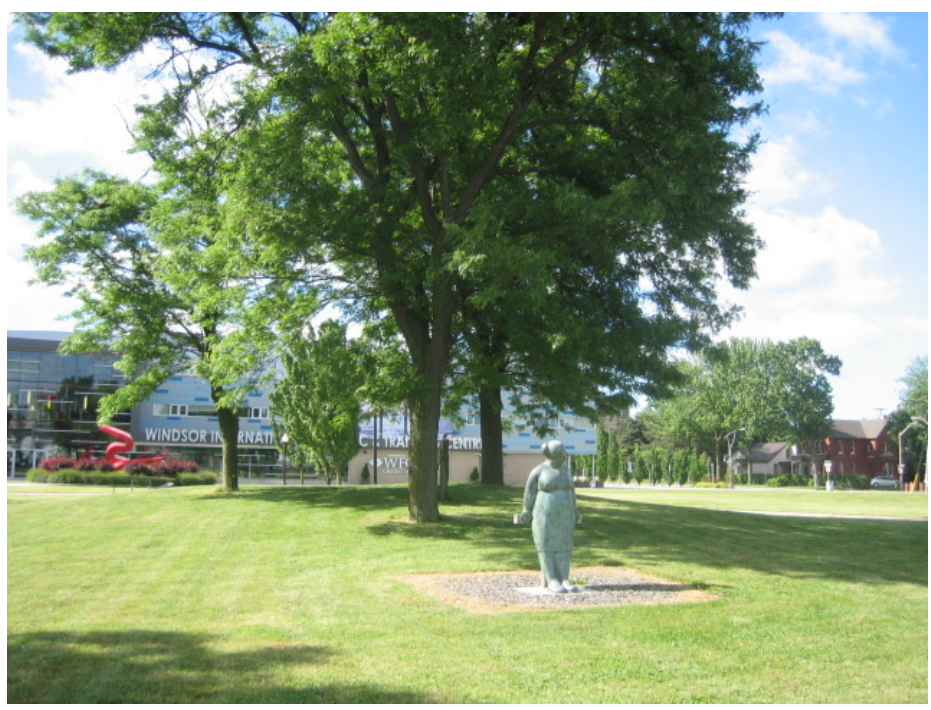

Source: Author.

Figure 4. Unused site of sports arena in downtown Windsor.

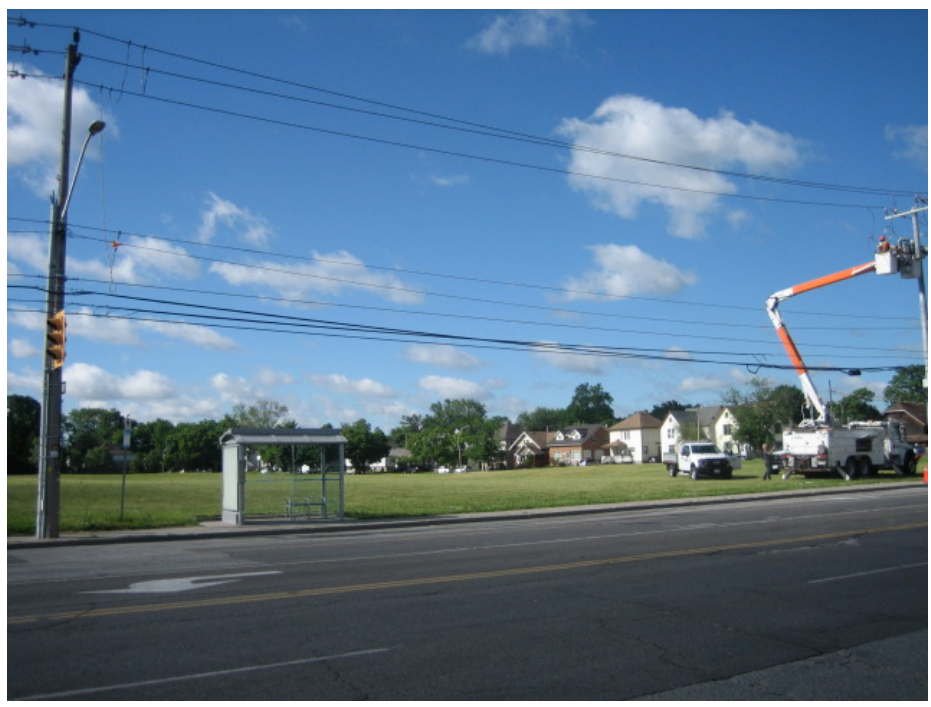

Source: Author

Figure 5. Former site of closed hospital in Wellington-Crawford neighbourhood in Windsor.

recession [39]. House prices may decline during periods of high adult unemployment when residents are earning and saving less, and possibly moving out [40]. Sales and prices may decline even further during a national economic recession that originates in another economic sector than adult (un-)employment, such as the four just before or during the study period in 1980, 1981-1982, 1990-1992, and 2007-2009 [41] [42] [43] [44], includes graph; operationally, recessionary years are coded 1 , and other years, zero. Together, a chronic high unemployment rate after the end of a recession may depress house prices for several more years in an unresilient neighbourhood such as an inner city one [14] [39]. Monthly unemployment rates are available for metropolitan Windsor 
[45].

The third variable in Equation (1), $H C_{n}^{t}$, is the ongoing cost of home ownership including requirements and interest rates for mortgages. Decisions about housing purchase and upkeep typically depend on the availability of financing from private financial institutions as well as the ratio of loan to equity that is ultimately related to residents' savings and earnings [46] [47]. Both components are measured in Canada's mortgage interest cost index on a monthly basis as a constituent of the consumer price index [48] -although this national index encompasses more expensive housing markets than that of Windsor [49]. Note that this mortgage interest cost index is not correlated with presence or absence of an economic recession in Canada, thereby confirming the effectiveness of banking regulations against subprime mortgages during the 2000s.

The last variable in Equation (1), $H P_{n}^{t}$, represents the appreciation or depreciation of house prices in the market. This however may be less salient herein than in Carson and Dastrup's [16] study where it refers to house price changes in a city during the decade until the great recession of 2009. It in any case will be endogenous with changes in prices for a proportion of metropolitan Windsor's monthly house sales located in two study neighbourhoods (e.g. [50]).

\section{Three Housing Price Models}

Occurrences of local events will be independent variables in multiple regressions having a hybrid model's predicted annual percentage changes in homes' prices in each neighbourhood as the dependent variable. These predictions will have statistically controlled for differences in homes' times of sale and resale, changes in their attributes of the dwelling and neighbourhood, and compositions of their neighbouring sold homes. Moreover, hybrid models' predicted changes in prices should provide more precise indicators of change in a neighbourhood from prices and attributes of sold and resold homes through time [17] [51]. This is because a hybrid price model is the statistical synthesis of a single sales hedonic housing price model and a repeat sales model of the same data.

The more frequently-tested hedonic housing price model assumes that a oncesold $(i=1, \cdots, I)$ house's price at a $(t=1, \cdots, T)$ time $t, p_{i}^{t}$, is a function of its $(k=1, \cdots, K)$ attributes at that time, $\left\{x_{k, i}^{t}\right\}$, the composition of its $(m=1, \cdots, M)$ neighbouring sold homes up to that time, $\left\{\lambda_{m, i}^{t}\right\}$, and the time of sale itself (e.g. year), $d_{i}^{t}$, equalling 1 for the time of sale and zero otherwise:

$$
\mathrm{LN} p_{i}^{t}=a+\dot{\boldsymbol{\beta}} \boldsymbol{x}_{i}^{t}+\dot{A} \lambda_{i}^{t}+\dot{\gamma} \boldsymbol{d}_{i}^{t}+\eta_{i}+e_{i}^{t}
$$

where $\boldsymbol{\beta}=\left\{\beta_{k}\right\}$ is a $K \times 1$ vector of implicit prices of attributes, and $\boldsymbol{x}_{i}^{t}=\left\{x_{k, i}^{t}\right\}$ is a $K \times 1$ vector of observed attributes of an $t^{\text {th }}$ house at sale time $t$, similarly $\boldsymbol{A}=\left\{\alpha_{m}\right\}$ is a $M \times 1$ vector of marginal implicit prices, and $\lambda_{i}^{t}=\left\{\lambda_{m, i}^{t}\right\}$ is a $M$ $\times 1$ vector of observed correlations with an $i^{\text {th }}$ house's neighbouring sold homes up to sale time $t ; \gamma$ is the $T \times 1$ vector of price changes through time and $\boldsymbol{d}_{i}^{t}$ is the $T \times 1$ vector of time-dependent dummy variables for this $I^{\text {th }}$ house. And an error term $\varepsilon_{i}^{t}$ for this home is decomposed into a time-independent specifica- 
tion error $\eta_{i}$ and a white noise process $e_{i}^{t}$.

A single sales hedonic price model does not differentiate between $I$ once-sold homes at time $t$ and $J$ resold homes also indicated as selling at time $t$ when sold either the first time or the second time or more. In comparison, the frequentlytested repeat sales model distinguishes each $(j=1, \cdots, J)$ home sold more than once from the $I$ once-sold homes by its $t$ time of original resale and $\tau$ later time of resale. A $f^{\text {th }}$ home's difference in resale price at time $\tau$ versus sale price at time $t,\left(p_{j}^{\tau}-p_{j}^{t}\right)$, is a function of its change in each $k^{\text {th }}$ attribute between these times, $\left(x_{k, j}^{\tau}-x_{k, j}^{t}\right)$, the change in its composition of $M$ neighbouring sold homes between those times, $\left(\lambda_{m, j}^{\tau}-\lambda_{m, j}^{t}\right)$, and the time between sale and resale, $\left(d_{j}^{\tau}-d_{j}^{t}\right)$, coded $(-1)$ for time of sale, 1 for time of resale, and zero otherwise in a time-dependent dummy variable, $\delta_{j}^{\tau}$ :

$$
\left(\mathrm{LN} p_{j}^{\tau}-\mathrm{LN} p_{j}^{t}\right)=\dot{\boldsymbol{\beta}}\left(\boldsymbol{x}_{j}^{\tau}-\boldsymbol{x}_{j}^{t}\right)+\boldsymbol{A}^{\prime}\left(\lambda_{j}^{\tau}-\lambda_{j}^{t}\right)+\dot{\gamma}_{j}^{\tau}+e_{j}^{\tau}-e_{j}^{t}
$$

where $\boldsymbol{A}=\left\{\alpha_{m}\right\}$ and $\boldsymbol{\beta}=\left\{\beta_{k}\right\}$ are now respective $M \times 1$ and $K \times 1$ vectors of marginal implicit price changes; and $\lambda_{j}^{t}=\left\{\lambda_{m, j}^{t}\right\}$ and $\lambda_{j}^{\tau}=\left\{\lambda_{m, j}^{\tau}\right\}$ are $M \times 1$ vectors of a $f^{\text {th }}$ house's correlations with neighbouring sold homes at its sale and resale times, and $\boldsymbol{x}_{j}^{t}=\left\{x_{k, j}^{t}\right\}$ and $\boldsymbol{x}_{j}^{\tau}=\left\{x_{k, j}^{\tau}\right\}$ are $K \times 1$ vectors of its observed attributes at those times. $\gamma$ is still the $T \times 1$ vector of price changes through time but $\delta_{j}^{\tau}$ is the $T \times 1$ vector of time-differenced dummy variables for a $f^{\text {th }}$ house. And the error terms for a $f^{\text {th }}$ house are white noise processes of $e_{j}^{t}$ at time $t$ and $e_{j}^{\tau}$ at time $\tau$.

A hybrid price model exploits the inclusion of these repeat sales of the same homes in a dataset for updating the error structure of a single sales hedonic price model by removing unobserved specification errors due to dependencies between repeat sales [52]. The derivation by Jones [53] of these error terms for inclusion in a covariance matrix corresponds with the analysis of the random effects model by Greene [54]. The error variance of a single sales regression in Equation (2) is estimated with the residuals, $\left\{\hat{\varepsilon}_{h}\right\}$, from the ordinary least squares regression for all $(h=1, \cdots, H(=I+J))$ once-sold and resold homes. It also has an adjustment for lost degrees of freedom for $K+M$ coefficients of attributes of homes and their neighbours, $T$ coefficients of their aggregated times of sale, and the constant intercept:

$$
\hat{\sigma}_{\varepsilon}^{2}=\left(\frac{1}{H-K-M-T-1}\right) \sum_{h=1}^{H} \hat{\varepsilon}_{h}^{2}
$$

The error variance of a repeat sales regression in Equation (3) is estimated with the $(j=1, \cdots, J)$ residuals, $\left\{\hat{\xi}_{j}\right\}$, from this regression, also with an adjustment for lost degrees of freedom for $K+M$ coefficients of attributes of homes and their neighbours, and $T$ coefficients of their aggregated times of sale, but no constant intercept:

$$
\hat{\sigma}_{e}^{2}=\frac{1}{2}\left(\frac{1}{J-K-M-T}\right) \sum_{j=1}^{J} \hat{\xi}_{j}^{2}
$$

As explained in another study [52], these estimates of error variances in Equa- 
tions (4) and (5) are elements of an estimated covariance matrix from which are decomposed values of a $p$-value matrix for rescaling data of the observed $I$ once-sold homes and $J$ resold homes in a hybrid price model. As a result, this hybrid price model will have lower standard errors of regression coefficients for more precise predictions of house prices than the single sales hedonic model, while also having statistically-similar regression coefficients [17] [20] [52] [55] [56].

\section{Observations' Data}

Required data for calibrating a hybrid price model are effectively those required by both a single sales hedonic price model and a repeat sales model [57]. A hedonic price model requires time-of-sale data for sold homes' prices and attributes of their dwelling unit and neighbourhood, and compositions of their neighbouring sold homes. The more onerous required data for a repeat sales model are the changes in prices of the same homes between times of sale and resale, and the corresponding changes in their attributes of the dwelling unit and neighbourhood, and differences in the compositions of neighbouring sold homes.

This study's data are for all 2,920 inhabitable single-detached and duplex houses sold through the Multiple Listing Service in two inner-city neighbourhoods in Windsor, Ontario. These data were collected from the beginning of January 1981 in one neighbourhood named Glengarry (Figure 6), and from January 1986 in another named Wellington-Crawford (Figure 7), until the end of December 2018 in each neighbourhood. Data from the early-1980s are retained for the former neighbourhood's study period as these were unusual years for house sales. Addresses of sold houses in each neighbourhood are plotted on online maps available from

http://web2.uwindsor.ca/courses/sociology/phipps/agp/gwc/gwcmaps.html.

Nine attributes of the dwelling unit were coded from the MLS listing at each

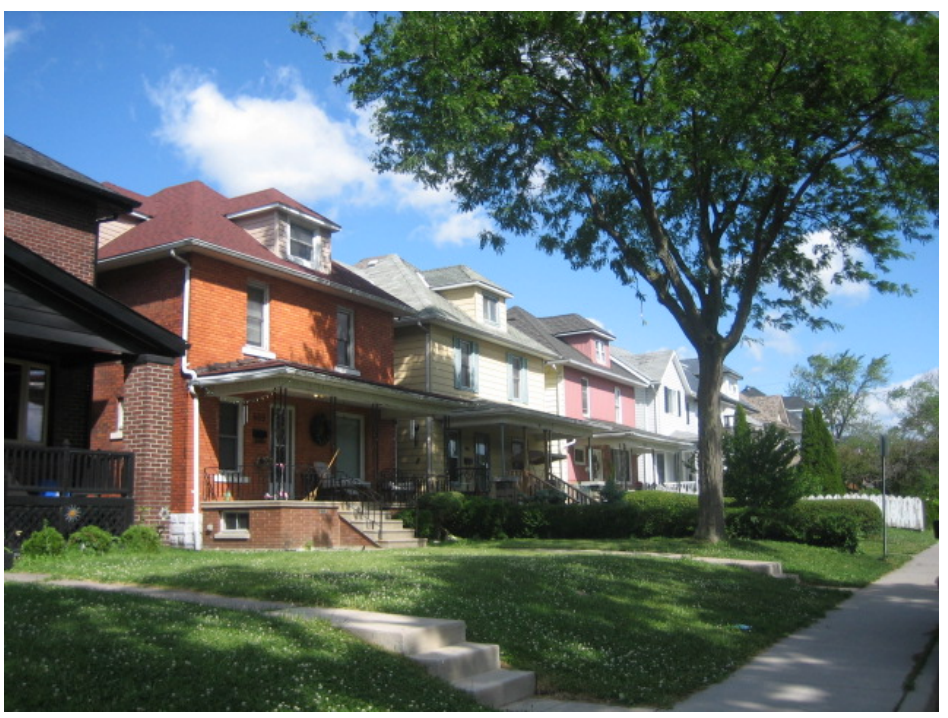

Source: Author.

Figure 6. Example residential street in Glengarry neighbourhood in Windsor. 


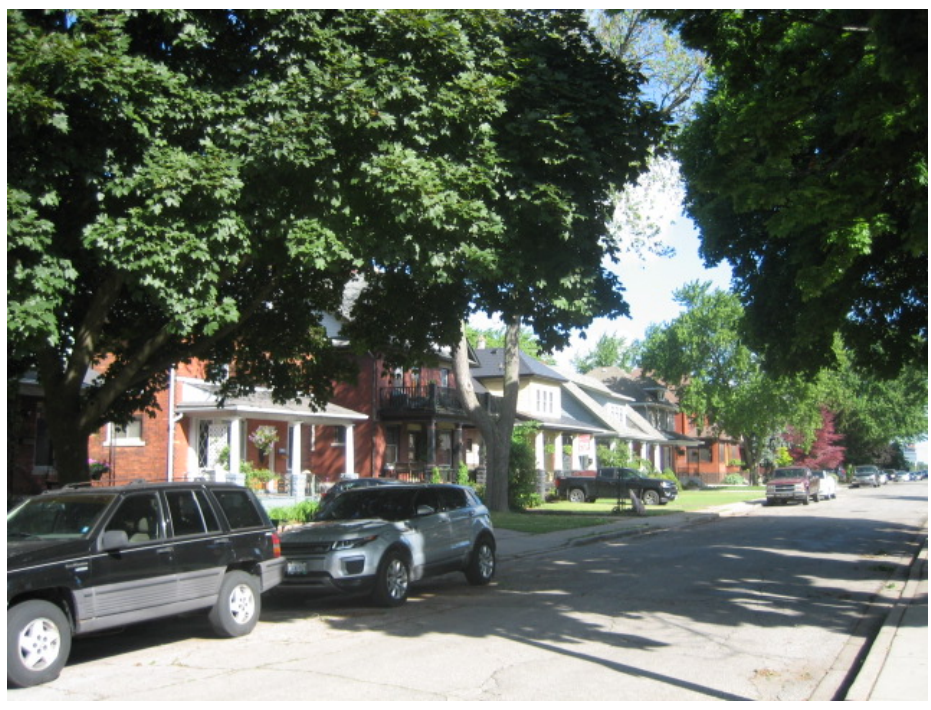

Source: Author.

Figure 7. Example residential street in Wellington-Crawford neighbourhood in Windsor.

time of sale, and these are lot size in thousands of square feet; numbers of garages, bedrooms, bathrooms, and storeys; and dummies for exterior brick finish, finished full basement, central air conditioning, and home's condition coded from a realtor's summary evaluation as -1 for poor, 0 for normal, and 1 for excellent (Table 1). Eight attributes of the neighbourhood are the median annual income in thousands of dollars for adults in a dissemination area (DA); and percentages in a DA of: dwelling units needing major repairs, households with at least one child at home, owner occupiers, visible minority population, and adults who are blue-collar workers, unattached, or university educated.

Differences between sold homes' attributes justify distinct analyses of each neighbourhood's data: Five attributes of the neighbourhood have statistically significant different means in the two study neighbourhoods, as well as four of the dwelling unit based on non-overlapping 95\% confidence intervals in the table. Note the attributes of the neighbourhood are from the 2001, 2006, 2011 or 2016 census closest to the time of sale or resale of a home; and they are appended to its data after locating it inside the boundaries of one of 25 DAs in Windsor, Ontario. The year 2001 was the first for subdivision of Canadian census metropolitan areas such as Windsor, Ontario, into DAs with the small-area data used in this study [58]. Theretofore, two study neighbourhoods were covered by four larger census tracts having not only different boundaries but also different variables than subsequent dissemination areas.

Boundaries of the mostly rectangular dissemination areas, approximately one-half kilometre by one-quarter kilometre in size, and aligned with a grid street pattern, may delineate a visual and interactional neighbourhood of homes in this part of the city. However, the neighbourhood of a sold home may have a separate effect from that of its attributes and changes in them if a home's sale price is correlated with prices of $M$ recently-sold neighbouring homes [59] [60]. 
Table 1. Variables' descriptive statistics and hybrid models' regression coefficients.

\begin{tabular}{|c|c|c|c|c|c|c|c|c|c|c|c|}
\hline \multirow{3}{*}{ Component } & \multirow{3}{*}{ Variable } & \multicolumn{5}{|c|}{ Glengarry } & \multicolumn{5}{|c|}{ Wellington-Crawford } \\
\hline & & \multirow{2}{*}{$\begin{array}{c}\text { Attribute } \\
95 \% \text { CI } \\
\text { Lower }\end{array}$} & \multirow{2}{*}{$\begin{array}{c}\text { Attribute } \\
95 \% \text { CI } \\
\text { Upper }\end{array}$} & \multicolumn{3}{|c|}{ Hybrid Model } & \multirow{2}{*}{$\begin{array}{l}\text { Attribute } \\
95 \% \text { CI } \\
\text { Lower }\end{array}$} & \multirow{2}{*}{$\begin{array}{c}\text { Attribute } \\
95 \% \text { CI } \\
\text { Upper }\end{array}$} & \multicolumn{3}{|c|}{ Hybrid Model } \\
\hline & & & & B & $\begin{array}{l}\text { Std. } \\
\text { Error }\end{array}$ & $\begin{array}{c}\text { Significance } \\
\text { level }\end{array}$ & & & B & $\begin{array}{l}\text { Std. } \\
\text { Error }\end{array}$ & $\begin{array}{l}\text { Significance } \\
\text { level }\end{array}$ \\
\hline \multirow[t]{8}{*}{$\begin{array}{c}\text { Attribute of } \\
\text { Neighbourhood }\end{array}$} & $\begin{array}{l}\text { Median adult income } \\
\text { in a DA }(\$ 000)\end{array}$ & 21.44 & 22.01 & 0.012 & 0.003 & 0.000 & 20.97 & 21.47 & 0.004 & 0.002 & 0.009 \\
\hline & $\begin{array}{c}\text { Blue collar workers in } \\
\text { a DA }(\%)\end{array}$ & 17.18 & 18.02 & 0.004 & 0.001 & 0.003 & 15.78 & 16.68 & 0.000 & 0.001 & 0.891 \\
\hline & $\begin{array}{l}\text { Dwelling units in } \\
\text { need of major repairs } \\
\text { in a DA (\%) }\end{array}$ & 13.70 & 14.57 & -0.003 & 0.001 & 0.032 & 10.01 & 10.57 & -0.003 & 0.001 & 0.010 \\
\hline & $\begin{array}{c}\text { Families with at least } \\
\text { one child at home in a } \\
\text { DA (\%) }\end{array}$ & 45.91 & 47.87 & -0.002 & 0.001 & 0.158 & 48.56 & 49.96 & -0.004 & 0.001 & 0.000 \\
\hline & $\begin{array}{c}\text { Owner occupiers in a } \\
\text { DA (\%) }\end{array}$ & 37.89 & 39.15 & 0.001 & 0.001 & 0.405 & 33.46 & 34.99 & 0.001 & 0.001 & 0.090 \\
\hline & $\begin{array}{l}\text { Unattached adult } \\
\text { residents in a DA (\%) }\end{array}$ & 55.16 & 56.02 & -0.002 & 0.002 & 0.343 & 55.71 & 56.66 & 0.006 & 0.001 & 0.000 \\
\hline & $\begin{array}{l}\text { University educated } \\
\text { adults in a DA (\%) }\end{array}$ & 17.61 & 18.57 & 0.004 & 0.002 & 0.003 & 23.74 & 24.71 & 0.001 & 0.001 & 0.324 \\
\hline & $\begin{array}{l}\text { Visible minority } \\
\text { residents in a DA (\%) }\end{array}$ & 30.74 & 32.28 & -0.002 & 0.001 & 0.166 & 30.06 & 30.93 & -0.002 & 0.001 & 0.028 \\
\hline \multirow[t]{9}{*}{$\begin{array}{c}\text { Attribute of } \\
\text { Dwelling Unit }\end{array}$} & Lot size (000s sq ft) & 3.73 & 3.86 & 0.05 & 0.01 & 0.000 & 4.05 & 4.20 & 0.03 & 0.01 & 0.000 \\
\hline & $\begin{array}{l}\text { Basement }(1= \\
\text { Finished full })\end{array}$ & 0.20 & 0.24 & 0.02 & 0.02 & 0.352 & 0.34 & 0.38 & 0.05 & 0.01 & 0.001 \\
\hline & $\begin{array}{c}\text { Central air } \\
\text { conditioning } \\
(1=\text { Yes })\end{array}$ & 0.27 & 0.33 & 0.10 & 0.02 & 0.000 & 0.39 & 0.43 & 0.15 & 0.02 & 0.000 \\
\hline & $\begin{array}{l}\text { Exterior brick finish } \\
\qquad(1=\text { Yes })\end{array}$ & 0.34 & 0.40 & 0.13 & 0.03 & 0.000 & 0.35 & 0.39 & 0.11 & 0.02 & 0.000 \\
\hline & Bathrooms (Number) & 1.62 & 1.69 & 0.05 & 0.02 & 0.002 & 1.64 & 1.71 & 0.09 & 0.01 & 0.000 \\
\hline & Bedrooms (Number) & 3.55 & 3.67 & 0.05 & 0.01 & 0.000 & 3.50 & 3.62 & 0.04 & 0.01 & 0.000 \\
\hline & Garage (Number) & 0.45 & 0.53 & 0.07 & 0.01 & 0.000 & 0.37 & 0.44 & 0.06 & 0.01 & 0.000 \\
\hline & Storeys (Number) & 1.74 & 1.80 & 0.12 & 0.02 & 0.000 & 1.75 & 1.79 & 0.01 & 0.02 & 0.565 \\
\hline & $\begin{array}{l}\text { House's Condition } \\
\quad(-1=\text { Poor, } 0= \\
\text { Normal, } 1=\text { Excellent })\end{array}$ & -0.02 & 0.00 & 0.38 & 0.04 & 0.000 & 0.00 & 0.02 & 0.32 & 0.03 & 0.000 \\
\hline Value of & Eigenvector 01 & -0.05 & -0.02 & 0.018 & 0.03 & 0.468 & -0.06 & -0.04 & 0.028 & 0.020 & 0.162 \\
\hline Eigenvector & Eigenvector 03 & -0.02 & 0.02 & -0.021 & 0.02 & 0.389 & -0.02 & 0.01 & -0.030 & 0.018 & 0.097 \\
\hline Year of Sale & 1981 & & & 0 & & & & & & & \\
\hline \multirow[t]{3}{*}{ or Resale } & 1982 & & & -0.26 & 0.08 & 0.002 & & & & & \\
\hline & 1983 & & & -0.29 & 0.08 & 0.000 & & & & & \\
\hline & 1984 & & & -0.14 & 0.08 & 0.071 & & & & & \\
\hline
\end{tabular}




\section{Continued}

\begin{tabular}{|c|c|c|c|c|c|c|c|}
\hline & 1985 & 0.13 & 0.07 & 0.073 & & & \\
\hline & 1986 & 0.40 & 0.08 & 0.000 & 0 & & \\
\hline & 1987 & 0.52 & 0.08 & 0.000 & 0.11 & 0.04 & 0.003 \\
\hline & 1988 & 0.71 & 0.07 & 0.000 & 0.29 & 0.03 & 0.000 \\
\hline & 1989 & 0.99 & 0.07 & 0.000 & 0.54 & 0.04 & 0.000 \\
\hline & 1990 & 0.91 & 0.09 & 0.000 & 0.53 & 0.04 & 0.000 \\
\hline & 1991 & 0.92 & 0.09 & 0.000 & 0.51 & 0.04 & 0.000 \\
\hline & 1992 & 0.95 & 0.08 & 0.000 & 0.47 & 0.04 & 0.000 \\
\hline & 1993 & 0.99 & 0.09 & 0.000 & 0.59 & 0.05 & 0.000 \\
\hline & 1994 & 1.07 & 0.08 & 0.000 & 0.58 & 0.04 & 0.000 \\
\hline & 1995 & 1.10 & 0.09 & 0.000 & 0.61 & 0.04 & 0.000 \\
\hline & 1996 & 1.12 & 0.09 & 0.000 & 0.65 & 0.05 & 0.000 \\
\hline & 1997 & 1.06 & 0.08 & 0.000 & 0.70 & 0.04 & 0.000 \\
\hline & 1998 & 1.12 & 0.08 & 0.000 & 0.64 & 0.05 & 0.000 \\
\hline & 1999 & 1.09 & 0.08 & 0.000 & 0.61 & 0.05 & 0.000 \\
\hline & 2000 & 1.03 & 0.08 & 0.000 & 0.67 & 0.04 & 0.000 \\
\hline & 2001 & 1.19 & 0.09 & 0.000 & 0.66 & 0.05 & 0.000 \\
\hline & 2002 & 1.27 & 0.10 & 0.000 & 0.74 & 0.05 & 0.000 \\
\hline & 2003 & 1.29 & 0.10 & 0.000 & 0.72 & 0.05 & 0.000 \\
\hline & 2004 & 1.40 & 0.10 & 0.000 & 0.78 & 0.05 & 0.000 \\
\hline & 2005 & 1.35 & 0.10 & 0.000 & 0.71 & 0.05 & 0.000 \\
\hline & 2006 & 1.21 & 0.10 & 0.000 & 0.67 & 0.05 & 0.000 \\
\hline & 2007 & 1.27 & 0.10 & 0.000 & 0.65 & 0.06 & 0.000 \\
\hline & 2008 & 0.99 & 0.10 & 0.000 & 0.49 & 0.05 & 0.000 \\
\hline & 2009 & 0.90 & 0.09 & 0.000 & 0.35 & 0.05 & 0.000 \\
\hline & 2010 & 1.02 & 0.10 & 0.000 & 0.42 & 0.05 & 0.000 \\
\hline & 2011 & 0.86 & 0.09 & 0.000 & 0.42 & 0.05 & 0.000 \\
\hline & 2012 & 0.98 & 0.10 & 0.000 & 0.50 & 0.05 & 0.000 \\
\hline & 2013 & 1.07 & 0.09 & 0.000 & 0.53 & 0.05 & 0.000 \\
\hline & 2014 & 1.10 & 0.10 & 0.000 & 0.61 & 0.05 & 0.000 \\
\hline & 2015 & 1.14 & 0.09 & 0.000 & 0.66 & 0.05 & 0.000 \\
\hline & 2016 & 1.40 & 0.09 & 0.000 & 0.83 & 0.04 & 0.000 \\
\hline & 2017 & 1.61 & 0.10 & 0.000 & 1.10 & 0.05 & 0.000 \\
\hline & 2018 & 1.76 & 0.10 & 0.000 & 1.29 & 0.04 & 0.000 \\
\hline Constant & & 9.237 & 0.19 & 0.000 & 9.919 & 0.11 & 0.000 \\
\hline R-squared & & $97 \%$ & & & $98 \%$ & & \\
\hline $\begin{array}{l}\text { Degrees of } \\
\text { Freedom }\end{array}$ & & 1226 & & & 1518 & & \\
\hline
\end{tabular}

Source: Author. 
These spatial autocorrelations are represented by the $\left\{\lambda_{m, i}^{t}\right\}$ in Equations (2) and (3), and they are calculated in this study by means of eigenvector spatial filtering for every 12 sold homes up to and including an $t^{\text {th }}$ one [61] [62] [63]. In other words, the potential correlation between an $i^{\text {th }}$ sold home's location and those of nearby sold homes in the prior three or four months (based on 3.6 average monthly sales in Wellington-Crawford and 2.8 in Glengarry) is summarized by the eigenvalues and eigenvectors from decomposing:

$$
\left(I-\frac{1 \mathbf{i}}{M}\right) C_{i}^{t}\left(I-\frac{1 \mathbf{1}}{M}\right)
$$

where $I$ is the $M \times M$ identity matrix; 1 is an $M \times 1$ vector of $1 \mathrm{~s}$, and $\mathbf{i}$ is the transpose of them; and $C_{i}^{t}$ measures the spatial weights such as represented by inverse distances between $M$ sold houses including the $i^{\text {th }}$ one during a period before its sale or resale at time $t$.

This study's sequential calculations for a small number of neighbouring sold homes have at least three methodological advantages over other studies' calculations of eigenvalues and eigenvectors for the full spatial weights matrix between sold homes. First, only sales of neighbouring homes are assumed to be influential during the prior period to the home's sale, and so "future observations" are not included as in another study [[64], p. 23]. Second, relatively few eigenvalues and eigenvectors are extracted from each of these recently-sold neighbouring homes' spatial weights matrices. Salient eigenvectors are not selected after-thefact from potentially thousands for a full matrix as in another study (e.g. [62]). And finally, an eigenvector's value for a home at time of sale can be differenced from its value at time of resale in a repeat sales model.

Just as a repeat sales model analyzes the difference between a home's eigenvector values at times of sale and resale, it also analyzes the difference between each of a resold home's attributes of the dwelling unit and neighbourhood at those times. Up to approximately one-third of resold homes have a higher or lower predicted price with change in each attribute. In total, average percentages of these predicted prices' changes are statistically similar for eight of nine attributes of the dwelling unit; six of eight attributes of the neighbourhood; and both values of their eigenvectors based on overlapping $95 \%$ confidence intervals. Owing to the long study periods in two neighbourhoods, resold homes are 62\% (360) of (585) sold homes in Glengarry, and 59\% (447 of 760) in Wellington-Crawford. These produced 707 observed repeat sales in the former neighbourhood, and 868 in the latter after they were sold an average of approximately twice more: at respective medians of approximately five years and six months apart, and five years and one month apart.

\section{Results}

\subsection{Predicted Annual Percentage Changes in House Prices through Time}

Predicted annual percentage changes in house prices in a neighbourhood are 
calculated with each hybrid model's coefficients for years of sale or resale (Table 1); these are predicted changes in prices after statistically controlling for sold homes' attributes of the dwelling unit and neighbourhood. Each neighbourhood's annual percentage changes are dependent variables for testing this study's primary research hypothesis about fluctuations in prices of homes during occurrences of local events. In reality in both neighbourhoods, annual percentage changes and their 95\% confidence intervals have different trends during three periods since 1981 or 1986 (Figure 8). Two upward trends are however virtually offset by a longer downward trend. Hence, marginal non-monotonic improvements in real estate value are inferred for both neighbourhoods' house prices through time.

In detail, the first period until 1989 has annual percentage increases in house prices' averaging 24\% in Glengarry (G) between 1984 and 1989, and 20\% in Wellington-Crawford (WC) between 1987 and 1989; note this average increase in $\mathrm{G}$ excludes earlier percentage decreases in 1982 and 1983. Both average percentage increases are statistically significantly greater than zero, based on their 95\% confidence intervals (CI) calculated with between 16 and 85 annual sold houses in G and between 69 and 97 in WC (as displayed in the figure's light grey

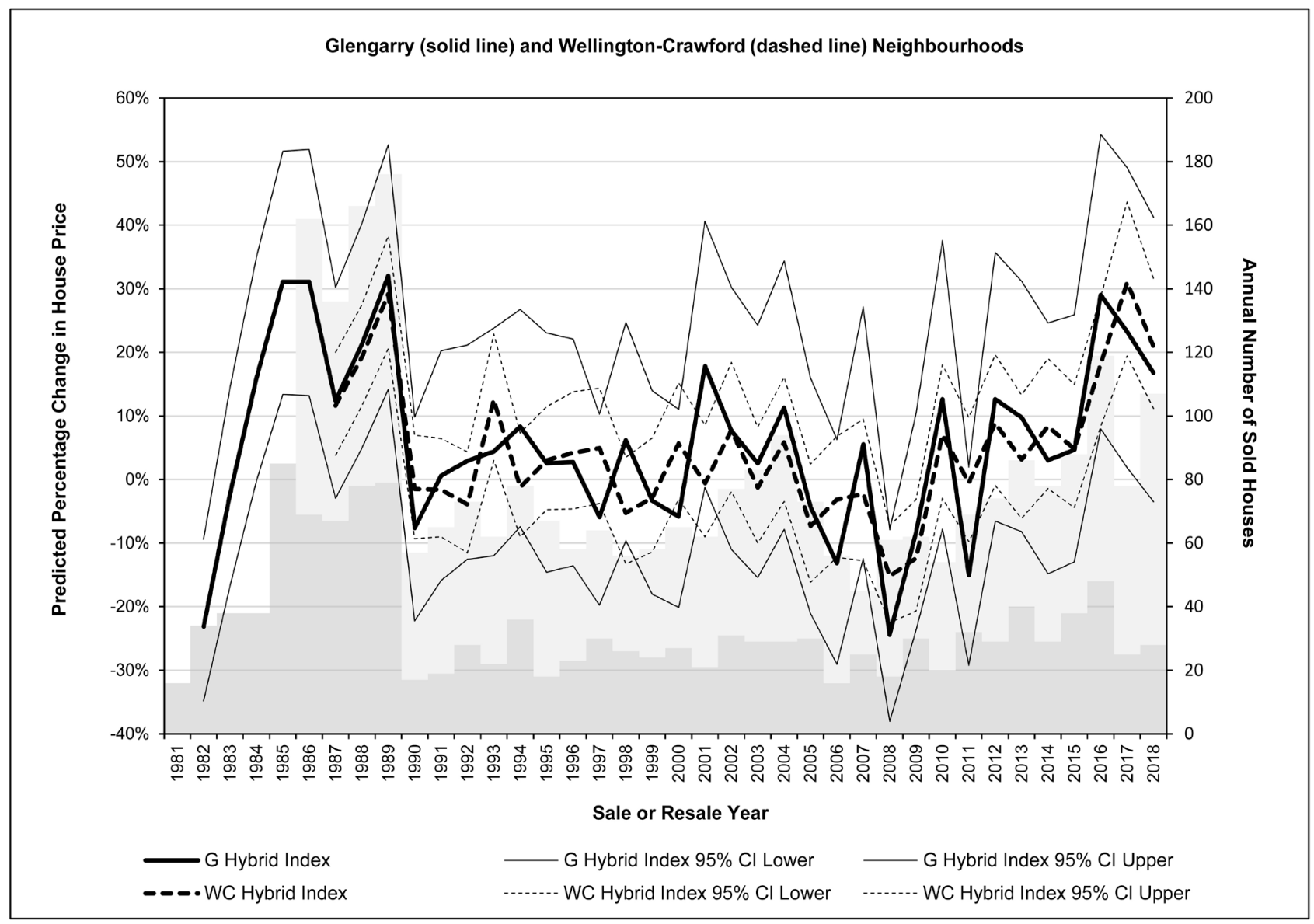

Source: Author.

Figure 8. Predicted annual percentage changes in house prices in two neighbourhoods. 
background).

The second period begins with precipitous percentage decreases in prices in 1990 in both neighbourhoods; and it ends with moderate decreases in G and WC during 2008 and then another similar decrease in G and a lesser one in WC during 2011. During this 22-year period, house prices fluctuate around no change, with zero average predicted annual percentage change for between 16 and 36 annual sales in $\mathrm{G}$ and between 20 and 65 in WC.

The third period from 2012 to 2018 has averages of $14 \%$ for predicted annual percentage increases in prices of 25 to 48 sold houses in G and 45 to 79 in WC, though neither average is statistically-significantly greater than zero based on their average 95\% CIs. Altogether, predicted annual changes in prices occurring solely due to the passage of time average out at $6 \%$ in G since 1981 and 5\% in WC since 1986; with average $95 \%$ CIs including zero in their ranges between $-11 \%$ and $26 \%$ in $\mathrm{G}$ and $-4 \%$ and $14 \%$ in WC.

Within these trends, significant percentage decreases in house prices occurred in G during 1982, 1990, 2008 and 2011, and in WC during 1990 and 2008, when each was a year of economic recession in Canada except for 2011. In fact, occurrences of recessions and adult unemployment rates are two independent variables with statistically significant regression coefficients at less than $5 \%$ level in multiple regressions, whose dependent variable is predicted annual percentage change in house prices in each neighbourhood (Table 2).

Predicted house prices have average $-19 \%$ and $-14 \%$ decreases in G and WC, respectively, during years of a recession compared to when it did not occur. They have further average $-3 \%$ decreases in both neighbourhoods for each percentage increase in the annual unemployment rate. House prices are predicted to have, for example, an approximate average $-14 \%$ decrease from 2008 to 2009 when the annual unemployment rate jumped from $9.2 \%$ to its $13.7 \%$ highest in the study period. The subsequent slow decline from this highest annual unemployment rate therefore prolonged the 2007-09 great recession's depreciated house prices until 2011 in both neighbourhoods.

Intercorrelations between the foregoing two independent variables and five remaining independent variables may explain the latter's statistically insignificant coefficients in the multiple regressions. Intercorrelations are greater than 0.53 or less than -0.58 for contemporaneous occurrences of recessions and planning activities in WC, and contemporaneous fluctuations of the unemployment rate and mortgage interest cost in WC; and then planning activities and corporate headquarters constructed in G, and planning activities and not only hospital closure and demolition but also arena built elsewhere in WC.

In comparison, none of three remaining statistically insignificant independent variables have intercorrelations greater than 0.48 or less than -0.49 with other independent variables. Annual changes in house prices in both neighbourhoods are therefore unrelated to prorated numbers of new residential building permits lagged by one year, the casinos' opening and closure, or the sculpture park's 
Table 2. Local event variables' descriptive statistics and regression coefficients.

\begin{tabular}{|c|c|c|c|c|c|c|c|c|c|c|}
\hline \multirow{3}{*}{ Variable } & \multicolumn{5}{|c|}{ Glengarry } & \multicolumn{5}{|c|}{ Wellington-Crawford } \\
\hline & \multirow{2}{*}{$\begin{array}{c}\text { Variable } \\
95 \% \text { CI } \\
\text { Lower }\end{array}$} & \multirow{2}{*}{$\begin{array}{c}\text { Variable } \\
95 \% \text { CI } \\
\text { Upper }\end{array}$} & \multicolumn{3}{|c|}{ Multiple Regression } & \multirow{2}{*}{$\begin{array}{c}\text { Variable } \\
95 \% \text { CI } \\
\text { Lower }\end{array}$} & \multirow{2}{*}{$\begin{array}{c}\text { Variable } \\
95 \% \text { CI } \\
\text { Upper }\end{array}$} & \multicolumn{3}{|c|}{ Multiple Regression } \\
\hline & & & B & $\begin{array}{l}\text { Std. } \\
\text { Error }\end{array}$ & $\begin{array}{c}\text { Significance } \\
\text { level }\end{array}$ & & & B & $\begin{array}{l}\text { Std. } \\
\text { Error }\end{array}$ & $\begin{array}{l}\text { Significance } \\
\text { level }\end{array}$ \\
\hline (Canada) Mortgage Interest Cost (Index) & 97 & 105 & 0.001 & 0.003 & 0.65 & 101 & 107 & 0.002 & 0.003 & 0.50 \\
\hline $\begin{array}{c}\text { (Canada) Recessions' occurrence } \\
(1=\text { Yes })\end{array}$ & 0.06 & 0.31 & -0.19 & 0.07 & 0.01 & 0.03 & 0.28 & -0.14 & 0.06 & 0.02 \\
\hline $\begin{array}{l}\text { (Windsor CMA) New DUs } \\
\text { (per } 1000 \text { pop; } 1 \text { year lag) }\end{array}$ & 5 & 7 & -0.01 & 0.01 & 0.06 & 5 & 8 & -0.01 & 0.01 & 0.24 \\
\hline $\begin{array}{c}\text { (Windsor CMA) Unemployment Rate } \\
(\%)\end{array}$ & 7.7 & 9.0 & -0.03 & 0.01 & 0.01 & 7.6 & 9.0 & -0.03 & 0.01 & 0.02 \\
\hline $\begin{array}{c}\text { (City of Windsor) Casinos' opening or } \\
\text { closure }(1=\text { Yes })\end{array}$ & 0.4 & 0.7 & 0.00 & 0.05 & 1.00 & 0.0 & 0.2 & -0.01 & 0.05 & 0.82 \\
\hline $\begin{array}{l}\text { (City of Windsor) Corporate HQ built } \\
\qquad(1=\text { Yes })\end{array}$ & 0.0 & 0.2 & -0.05 & 0.09 & 0.60 & 0.0 & 0.3 & -0.03 & 0.05 & 0.62 \\
\hline $\begin{array}{l}\text { (City of Windsor) Planning activities } \\
\qquad(1=\text { Yes })\end{array}$ & 0.1 & 0.3 & -0.05 & 0.09 & 0.62 & 0.0 & 0.3 & 0.01 & 0.06 & 0.85 \\
\hline $\begin{array}{l}\text { (City of Windsor) Riverfront sculpture } \\
\text { park }(1=\text { Yes })\end{array}$ & 0.0 & 0.2 & -0.04 & 0.07 & 0.60 & 0.0 & 0.3 & -0.06 & 0.05 & 0.23 \\
\hline (City of Windsor) Arena built elsewhere ( & $(1=$ Yes $)$ & & & & & 0.0 & 0.3 & 0.01 & 0.07 & 0.86 \\
\hline (City of Windsor) Hospital closure or den & nolition (- & $-1=$ Closur & $\mathrm{e}, 1=\mathrm{D}$ & molition & & -0.3 & 0.1 & 0.05 & 0.03 & 0.12 \\
\hline $\begin{array}{c}\text { Dependent Variable: Predicted annual } \\
\text { change in house prices (\%) }\end{array}$ & 0.01 & 0.10 & & & & 0.01 & 0.08 & & & \\
\hline Constant & & & 0.32 & 0.25 & 0.21 & & & 0.14 & 0.29 & 0.64 \\
\hline R-Squared & & & $50 \%$ & & & & & $64 \%$ & & \\
\hline Degrees of Freedom & & & 28 & & & & & 21 & & \\
\hline
\end{tabular}

Source: Author.

opening. Altogether, eight or ten independent variables account for $50 \%$ and $64 \%$ of the respective variation in predicted annual percentage changes in house prices in G and WC. Note that observed change in sale prices of homes in Windsor-Essex County is not an independent variable, as up to $5 \%$ of its monthly sales were in the two study neighbourhoods.

Coincidentally, hybrid models' predictions of annual percentage changes in house prices in two neighbourhoods are as hypothesized more precise than those of either the corresponding single sales hedonic model or repeat sales model, while three models have statistically the same regression coefficients. Each hybrid model's standard errors for 37 and 31 statistically significant regression coefficients of times of sale and resale are lower than the corresponding ones of the single sales hedonic model or repeat sales model, even though these standard errors have similar values (in results available from the author). Furthermore, these refined values of regression coefficients and their standard errors lead to hybrid models' significant statistical improvements in simple correlations be- 
tween observed and predicted homes' prices: G's hybrid model's R-squared of $97 \%$ is compared with $81 \%$ for the single sales hedonic model and $65 \%$ for the repeat sales model; and WC's hybrid model's $98 \%$ cf. $71 \%$ and $62 \%$.

\subsection{Predicted Percentage Changes in House Prices from Changes in Attributes}

Hybrid models' statistically significant regression coefficients for times of sale and resale, therefore, at best predict marginally improving annual house prices in both neighbourhoods during the past more than 30 years. They at worst predict stagnant or decreasing annual prices. Regardless, hybrid models' additional statistically significant regression coefficients for several attributes of the dwelling unit and neighbourhood predict compensatory percentage increases in sold homes' prices if these attributes changed (Table 1). For example, observed changes in at least three attributes of the dwelling unit between resold homes' times of sale and resale are predicted to double or triple the average $6 \%$ or $5 \%$ increase in price occurring in a neighbourhood solely with the passage of time.

Average $11 \%$ and $16 \%$ increases in price are predicted respectively for $17.5 \%$ of resold homes in G and 17\% in WC with installed central air conditioning between times of sale and resale. Also, $18.5 \%$ of resold homes in G and $24 \%$ in WC with more bedrooms may have respective average $5 \%$ and $4 \%$ increases in price for each additional bedroom between their times of sale and resale. Note that only approximately $3 \%$ of resold homes in a neighbourhood have each of the high value-adding improved house's condition in a realtor's summary evaluation, or the corresponding value-subtracting disimproved condition. In general, both G's and WC's hybrid models have statistically significant regression coefficients at less than the $5 \%$ level for eight attributes of the dwelling unit. These are lot size, presence of exterior brick finish or central air conditioning, numbers of garages, bedrooms or bathrooms, and house's condition classified as poor, normal or excellent from a realtor's summary evaluation; and number of storeys in $\mathrm{G}$ and presence of finished full basement in WC.

Changes to the dwelling unit from home improvements such as installation of central air conditioning and addition of a bedroom are therefore predicted to double or triple the marginal overall percentage increases in house prices from the passage of time alone. These predicted increases in prices however apply to a minority of approximately up to one-fifth of sold homes in $\mathrm{G}$ and one-quarter in WC, and not the remaining at least three quarters of sold homes having each unimproved or disimproved attribute of the dwelling unit.

Similar predicted percentage changes in prices for a minority of up to one-third of sold homes in G and more than one-third in WC may be caused by changes to attributes of the neighbourhood, such as inmovements of higher income residents including employed blue collar workers (Table 1). Homes' prices are predicted to decrease by $-5 \%$ in $\mathrm{G}$ and $-3 \%$ in WC if median adult income in a DA decreases by the average amount of $-\$ 4315$ in the former or $-\$ 7389$ in the latter. 
These are average decreases for $26 \%$ of resold homes in G and $31 \%$ in WC located in a DA with decreased median adult income between times of homes' sale and resale. Median adult income is one of two attributes of the neighbourhood with statistically significant coefficients in both neighbourhoods' models. The other is the percentage of dwelling units in need of major repairs in a DA.

Two or three remaining attributes of the neighbourhood emphasize differences between the two neighbourhoods. Two additional statistically significant attributes in $\mathrm{G}$ are percentages of blue-collar workers and university-educated adults in a DA. Three different statistically significant attributes in WC are percentages of unattached adult residents, families with at least one child at home, and visible minority residents in a DA. In particular in G, a relatively high average increase of $12 \%$ in blue collar workers in a DA is predicted to increase a sold home's price by $5 \%$ for $28 \%$ of resold homes located in a DA with an increasing percentage of blue collar workers between times of sale and resale.

Correspondingly in WC, a resold home has an approximate predicted pricedecrease of $-7 \%$ if it has the relatively highest $18 \%$ average increase in families with at least one child at home in their DA between times of sale and resale; and it is one of $38 \%$ of homes whose DA has more families with at least one child at home. Coincidentally, this attribute of the neighbourhood emphasizes a difference between two neighbourhoods' hybrid models. This attribute has a statistically-insignificant regression coefficient at 5\% level in G, even though it has the relatively highest $30 \%$ increase of an attribute of the $G$ neighbourhood for $31 \%$ of homes located in a DA with more families with at least one child at home between homes' times of sale and resale.

Last, each home's sale or resale price in each neighbourhood, and the change in it, is not statistically-significantly correlated with the locations of 12 houses including itself that sold sequentially during a typical three- or four-month period before its own sale. Neither spatial eigenvector has a statistically significant regression coefficient: even though the first one has a statistically significant positive coefficient at less than $5 \%$ level in WC's repeat sales model; and the third one has a statistically significant negative coefficient in WC's single sales hedonic model.

\section{Conclusions}

Sold houses are predicted to have increased in price only $6 \%$ in one inner-city neighbourhood in Windsor, Ontario, and 5\% in another since 1981 or 1986, respectively. These are very modest average percentage increases in predicted house prices in two neighbourhoods, though with no comparisons of predicted annual percentage changes in prices in other neighbourhoods during long study periods. In this study's two neighbourhoods, however, average predicted annual percentages might be inferred to be lower including zero (or higher) from $95 \%$ confidence intervals of regression coefficients calculated with minimums of 16 annual sold houses in one neighbourhood and 20 annual sold houses in the other. 
In other words, it might be an over-optimistic prediction of increased house prices at all in each neighbourhood, owing to relatively wide confidence intervals of predicted annual percentage changes. These annual percentage changes in house prices are inferred from Quigley's [17] hybrid price models of approximately 2900 houses in two inner-city neighbourhoods during the years since 1981 or 1986. Methodologically, these calibrated hybrid models have more precise predictions of changes in house prices than a hedonic price model or a repeat sales model.

Subsequent statistical analyses of these predicted annual percentage changes in prices identify two series of local events as especially correlated with precipitous decreases in prices at the end of two of three periods. These events under the $E C_{n}^{t}$ variable in Equation (1) are occurrences of years of recessions in Canada and years of high unemployment in metropolitan Windsor that were caused by activities of individuals and organizations outside of the neighbourhoods. Furthermore, high unemployment rates during and immediately after recessionary years tended to prolong declines in house prices for two or three more years. A practical implication of these results is that a planning or policy response, such as financial assistance toward home maintenance and improvement, may have to continue even after a recession is over for mitigating declining house prices in a neighbourhood. Besides, these two events' concurrence may neutralize possible effects of additional hypothesized local events such as the planning or opening of new buildings and facilities and the demolition of a closed one. None of these additional local events significantly increased prices during a 22-year period in the 1990s and 2000s when prices remained stagnant.

On the other hand, home improvements that change attributes of the dwelling unit, and different residents whose characteristics are attributes of the neighbourhood may raise sold homes' otherwise stagnant or decreasing prices. For example, predicted value-adding changes to the dwelling unit may include installation of central air conditioning and addition of a bedroom. Predicted value-adding changes to the neighbourhood may include movements of higher income residents including employed blue collar workers. Such changes are predicted by hybrid models' coefficients to double or triple the marginal overall percentage increases in house prices from the passage of time alone.

Even so, residents may require financial assistance with home improvements, as only up to one-quarter of sold or resold homes currently have each home improvement. The majority of sold homes in both neighbourhoods therefore have neither improvements nor predicted price increases. Furthermore, decreasing prices are predicted for a higher one-third of homes located in DAs where possibly lower income families with children have moved in. Yet, private improvements of such homes have been predicted by hybrid housing price models as counteracting neighbourhood deterioration in the past, while residents who require assistance with future improvements may have dispersed locations. Their unimproved and disimproved homes may be dispersed as changes in house prices 
and attributes are not spatially-autocorrelated in two neighbourhoods. For example, the geographic compositions of each 12 sold homes are predicted to have no statistical correlations with the twelfth one's price. In conclusion, this study's hybrid models have measured the changing prices and attributes of the dwelling unit and neighbourhood of sold and resold homes across two inner city neighbourhoods, but future more micro research will locate examples of homes with or without those changes.

\section{Acknowledgements}

Special thanks to Don Fuerth and Mike Tomek for providing access to the housing data analyzed in this study. Two anonymous reviewers' comments were helpful in this revision.

\section{Conflicts of Interest}

The author declares no conflicts of interest regarding the publication of this paper.

\section{References}

[1] Kitchen, P. and Williams, A. (2009) Measuring Neighborhood Social Change in Saskatoon, Canada: A Geographic Analysis. Urban Geography, 30, 261-288. https://doi.org/10.2747/0272-3638.30.3.261

[2] Delmelle, E.C. (2016) Mapping the DNA of Urban Neighborhoods: Clustering Longitudinal Sequences of Neighborhood Socioeconomic Change. Annals of the American Association of Geographers, 106, 36-56. https://doi.org/10.1080/00045608.2015.1096188

[3] Landis, J.D. (2016) Tracking and Explaining Neighborhood Socioeconomic Change in U.S. Metropolitan Areas between 1990 and 2010. Housing Policy Debate, 26, 2-52. https://doi.org/10.1080/10511482.2014.993677

[4] Greenlee, A.J. (2019) Assessing the Intersection of Neighborhood Change and Residential Mobility Pathways for the Chicago Metropolitan Area (2006-2015). Housing Policy Debate, 29, 186-212. https://doi.org/10.1080/10511482.2018.1476898

[5] Lupton, R. and Power, A. (2004) What We Know about Neighbourhood Change: A Literature Review, CASE Report 27. London School of Economics and Political Science, Centre for Analysis of Social Exclusion, London.

[6] Coulton, C., Theodos, B. and Turner, M.A. (2012) Residential Mobility and Neighborhood Change: Real Neighborhoods under the Microscope. Cityscape: A Journal of Policy Development and Research, 14, 55-89.

[7] Galster, G.C. and Tatian, P. (2009) Modeling Housing Appreciation Dynamics in Disadvantaged Neighborhoods. Journal of Planning Education and Research, 29, 7-22. https://doi.org/10.1177/0739456X09334141

[8] Prouse, V., Grant, J.L., Ramos, H. and Radice, M. (2015) Assessing Neighbourhood Change: Gentrification and Suburban Decline in a Mid-Sized City. Neighbourhood Change Research Partnership, Dalhousie University, Halifax.

[9] Knaap, G.-J. (1998) The Determinants of Residential Property Values: Implications for Regional Planning. Journal of Planning Literature, 12, 267-282. 
https://doi.org/10.1177/088541229801200301

[10] Malpezzi, S. (2002) Hedonic Pricing Models: A Selective and Applied Review. In: O'Sullivan, T. and Gibb, K., Eds., Housing Economics and Public Policy: Essays in Honor of Duncan Maclennan, Blackwell Science, Oxford, 67-89. https://doi.org/10.1002/9780470690680.ch5

[11] Des Rosiers, F., Dubé, J. and Thériault, M. (2011) Hedonic Price Modeling: Measuring Urban Externalities in Quebec. In: Thériault, M. and Des Rosiers, F., Eds., Modelling Urban Dynamics: Mobility, Accessibility and Real Estate Value, ISTE and Wiley, Hoboken, 255-283, Chapter 11.

[12] Spinney, J.E.L., Maoh, H. and Kanaroglou, P. (2014) Location and Land Values: Comparing the Accuracy and Fairness of Mass Appraisal Models. Canadian Journal of Regional Science, 37, 19-26.

[13] Ding, C. and Knaap, G.-J. (2002) Property Values in Inner-City Neighborhoods: The Effects of Homeownership, Housing Investment, and Economic Development. Housing Policy Debate, 13, 701-727. https://doi.org/10.1080/10511482.2002.9521462

[14] Wang, K. (2019) Housing Market Resilience: Neighbourhood and Metropolitan Factors Explaining Resilience before and after the US Housing Crisis. Urban Studies, 56, 2688-2708. https://doi.org/10.1177/0042098018800435

[15] Temkin, K. and Rohe, W.M. (1996) Neighborhood Change and Urban Policy. Journal of Planning Education and Research, 15, 159-170. https://doi.org/10.1177/0739456X9601500301

[16] Carson, R.T. and Dastrup, S.R. (2013) After the Fall: An Ex Post Characterization of Housing Price Declines across Metropolitan Areas. Contemporary Economic Policy, 31, 22-43. https://doi.org/10.1111/j.1465-7287.2011.00290.x

[17] Quigley, J.M. (1995) A Simple Hybrid Model for Estimating Real Estate Price Indices. Journal of Housing Economics, 4, 1-12. https://doi.org/10.1006/jhec.1995.1001

[18] Sirmans, G.S., Macpherson, D.A. and Zietz, E.N. (2005) The Composition of Hedonic Pricing Models. Journal of Real Estate Literature, 13, 3-46.

[19] Hill, R.J., Melser, D. and Syed, I. (2009) Measuring a Boom and Bust: The Sydney Housing Market 2001-2006. Journal of Housing Economics, 18, 193-205.

https://doi.org/10.1016/j.jhe.2009.07.010

[20] Goh, Y.M., Costello, G. and Schwann, G. (2012) Accuracy and Robustness of House Price Index Methods. Housing Studies, 27, 643-666. https://doi.org/10.1080/02673037.2012.697551

[21] Bourassa, S.C., Cantoni, E. and Hoesli, M. (2013) Robust Repeat Sales Indexes. Real Estate Economics, 41, 517-541. https://doi.org/10.1111/reec.12013

[22] Brasington, D.M. (2013) Housing Choice, Residential Mobility, and Hedonic Approaches. In: Fischer, M.M. and Nijkamp, P., Eds., Handbook of Regional Science, Springer-Verlag, Berlin Heidelberg, 147-166. https://doi.org/10.1007/978-3-642-23430-9_4

[23] Xiao, Y. (2017) Hedonic Housing Price Theory Review. In: Xiao, Y., Ed., Urban Morphology and Housing Market, Tongji University Press and Springer Nature, Singapore, Chapter 2, 11-40. https://doi.org/10.1007/978-981-10-2762-8_2

[24] Megbolugbe, I.F., Hoek-Smit, M.C. and Linneman, P.D. (1996) Understanding Neighbourhood Dynamics: A Review of the Contributions of William G. Grigsby. Urban Studies, 33, 1779-1795. https://doi.org/10.1080/0042098966367

[25] Redfearn, C.L. (2009) How Informative Are Average Effects? Hedonic Regression 
and Amenity Capitalisation in Complex Urban Housing Markets. Regional Science and Urban Economics, 39, 297-306.

https://doi.org/10.1016/j.regsciurbeco.2008.11.001

[26] Dubé, J., Legros, D., Thériault, M. and Des Rosiers, F. (2017) Measuring and Interpreting Urban Externalities in Real-Estate Data: A Spatio-Temporal Difference-inDifferences (STDID) Estimator. Buildings, 7, 1-23. https://doi.org/10.3390/buildings7020051

[27] Phipps, A.G. (2019) Use of Repeat House Sales to Measure Changes since the Earlyor Mid-1980s in Two Older-Urban Neighbourhoods in Windsor, Ontario. The Canadian Geographer, 63, 643-662. https://doi.org/10.1111/cag.12541

[28] Carter, T. (1991) Neighbourhood Improvement: The Canadian Experience. In: Alterman, R. and Cars, G., Eds., Neighbourhood Regeneration: An International EXperience, Mansell Publishing, London, 9-27.

[29] City of Windsor (2003) Glengarry-Marentette Waterfront Village Community Improvement Plan. Community Planners Inc., London.

https://www.citywindsor.ca/residents/planning/Plans-and-Community-Information /Know-Your-Community/Documents/Glengarry\%20Marentette\%20CIP.pdf

[30] City of Windsor (2006) City Centre West Community Improvement Plan. Planning and Building Services Department, City of Windsor.

https://www.citywindsor.ca/residents/planning/plans-and-community-information/ know-your-community/documents/ccw\%20cip\%20-\%20schedule\%205\%20-\%20city \%20centre\%20west $\% 20$ community\%20improvement $\% 20$ plan $\% 20$ incentive $\% 20$ prog rams.pdf

[31] Phipps, A.G. (2004) Crime and Disorder, and House Sales and Prices around the Casino Sites in Windsor, Ontario, Canada. The Canadian Geographer, 48, 403-432. https://doi.org/10.1111/j.0008-3658.2004.00068.x

[32] Schmidt, D. (2013) City Reverses Decision to Ease Up on Parking Lot Crackdown. The Windsor Star, A.1, 25 March.

[33] Des Rosiers, F., Thériault, M. and Villeneuve, P.-Y. (2000) Sorting Out Access and Neighbourhood Factors in Hedonic Modelling. Journal of Property Investment and Finance, 18, 291-315. https://doi.org/10.1108/14635780010338245

[34] Song, Y. and Knaap, G.-J. (2004) Measuring the Effects of Mixed Land Uses on Housing Values. Regional Science and Urban Economics, 34, 663-680. https://doi.org/10.1016/j.regsciurbeco.2004.02.003

[35] Pouyanne, G., Dantas, M. and Gaschet, F. (2016) The Effect of Current and Future Surrounding Land Use on Housing Prices: A Spatial Econometric Approach. Canadian Journal of Regional Science, 39, 39-49.

[36] Statistics Canada (2019) Table 17-10-0017-01 Total Population, Census Divisions and Census Metropolitan Areas, 1996 Census Boundaries. Government of Canada, Ottawa.

[37] Statistics Canada (2019) Table 17-10-0135-01 Population Estimates, July 1, by Census Metropolitan Area and Census Agglomeration, 2016 Boundaries. Government of Canada, Ottawa.

[38] Statistics Canada (2019) Table 34-10-0149-01 (Formerly CANSIM 027-0038) Canada Mortgage and Housing Corporation, Absorptions and Unabsorbed Inventory, Newly Completed Dwellings, by Type of Dwelling Unit in Census Metropolitan Areas, Monthly. Government of Canada, Ottawa.

[39] Dong, H. and Hansz, J.A. (2016) The Geography of the Recent Housing Crisis: The Role of Urban Form. Housing Policy Debate, 26, 159-171. 
https://doi.org/10.1080/10511482.2015.1038575

[40] Feijten, P. and van Ham, M. (2009) Neighbourhood Change... Reason to Leave? Urban Studies, 46, 2103-2122. https://doi.org/10.1177/0042098009339430

[41] Beltratti, A. and Morana, C. (2008) International House Prices and Macroeconomic Fluctuations. Journal of Banking and Finance, 34, 533-545. https://doi.org/10.1016/j.jbankfin.2009.08.020

[42] Martin, R.L. (2011) The Local Geographies of the Financial Crisis: From the Housing Bubble to Economic Recession and Beyond. Journal of Economic Geography, 11, 587-618. https://doi.org/10.1093/jeg/lbq024

[43] Nneji, O., Brooks, C. and Ward, C.W. (2013) House Price Dynamics and Their Reaction to Macroeconomic Changes. Economic Modelling, 32, 172-178. https://doi.org/10.1016/j.econmod.2013.02.007

[44] Bonham, M.S. (2017) Recession in Canada. The Canadian Encyclopedia. https://www.thecanadianencyclopedia.ca/en/article/recession

[45] Statistics Canada (2019) Table 14-10-0095-01 (Formerly CANSIM 282-0128) Labour Force Characteristics by Census Metropolitan Area, Three-Month Moving Average, Unadjusted for Seasonality. Government of Canada, Ottawa.

[46] Potepan, M.J. (1989) Interest Rates, Income, and Home Improvement Decisions. Journal of Urban Economics, 25, 282-294.

https://doi.org/10.1016/0094-1190(89)90051-X

[47] Case, K.E., Quigley J.M. and Shiller, R.J. (2012) Wealth Effects Revisited 1978-2012. Cowles Foundation Discussion Paper No. 1884, Cowles Foundation for Research in Economics, Yale University, New Haven.

[48] Statistics Canada (2019) Table 18-10-0004-01 (Formerly CANSIM 326-0020) Consumer Price Index, Monthly, Not Seasonally Adjusted. Government of Canada, Ottawa.

[49] Xu, A., Yélou, C. and Soumare, A. (2017) New Approach for Estimating the Mortgage Interest Cost Index, Catalogue No. 62F0014F2017002. Government of Canada, Ottawa.

[50] President of Windsor-Essex County Association of Realtors (2019) President's Report Residential Stats: Monthly Stats, 2019 April. Windsor-Essex County Association of Realtors, Windsor.

[51] Englund, R., Quigley, J.M. and Redfearn, C.L. (1998) Improved Price Indexes for Real Estate: Measuring the Course of Swedish Housing Prices. Journal of Urban Economics, 44, 171-196. https://doi.org/10.1006/juec.1997.2062

[52] Phipps, A.G. and Li, D. (2019) Calibration and Evaluation of Quigley's Hybrid Housing Price Model in Microsoft Excel. PLOS ONE, 14, e0215954. https://doi.org/10.1371/journal.pone.0215954

[53] Jones, C. (2009) Measuring Western Australian House Prices: Methods and Implications. Business School, Discussion Paper 09.10, The University of Western Australia, Crawley. https://core.ac.uk/download/pdf/6406674.pdf

[54] Greene, W.H. (2012) Econometric Analysis. 7th Edition, Prentice Hall, Boston.

[55] Jones, C. (2010) House Price Measurement: The Hybrid Hedonic Repeat-Sales Method. The Economic Record, 86, 95-97. https://doi.org/10.1111/j.1475-4932.2009.00596.x

[56] Fogarty, J.J. and Jones, C. (2011) Return to Wine: A Comparison of the Hedonic, Repeat Sales and Hybrid Approaches. Australian Economic Papers, 50, 147-156. https://doi.org/10.1111/j.1467-8454.2011.00416.x 
[57] Meese, R.A. and Wallace, N.E. (1997) The Construction of Residential House Price Indices: A Comparison of Repeat-Sales, Hedonic-Regression, and Hybrid Approaches. The Journal of Real Estate Finance and Economics, 14, 51-74.

[58] Statistics Canada (2016) Dictionary Census of Population: Dissemination Area (DA). Government of Canada, Ottawa.

http://www12.statcan.gc.ca/census-recensement/2016/ref/dict/geo021-eng.cfm

[59] Basu, S. and Thibodeau, T.G. (1998) Analysis of Spatial Autocorrelation in House Prices. Journal of Real Estate Finance and Economics, 17, 61-85. https://doi.org/10.1023/A:1007703229507

[60] Suriatini, I. (2006) Spatial Autocorrelation and Real Estate Studies: A Literature Review. Malaysian Journal of Real Estate, 1, 1-13.

[61] Griffith, D.A. (2012) Space, Time, and Space-Time Eigenvector Filter Specifications That Account for Autocorrelation. Estadística Española, 54, 7-34.

[62] Helbich, M. and Griffith, D.A. (2016) Spatially Varying Coefficient Models in Real Estate: Eigenvector Spatial Filtering and Alternative Approaches. Computers, Environment and Urban Systems, 57, 1-11.

https://doi.org/10.1016/j.compenvurbsys.2015.12.002

[63] Hu, L., Chun, Y. and Griffith, D.A. (2019) A Multilevel Eigenvector Spatial Filtering Model of House Prices: A Case Study of House Sales in Fairfax County, Virginia. ISPRS International Journal of Geo-Information, 8, 508. https://doi.org/10.3390/ijgi8110508

[64] Dubé, J. and Legros, D. (2013) A Spatio-Temporal Measure of Spatial Dependence: An Example Using Real Estate Data. Papers in Regional Science, 92, 19-30. 